\title{
An Overview on Microorganisms Contribute in Increasing Soil Fertility
}

\author{
Safi Ur Rehman Qamar ${ }^{1 *}$, Haroon ${ }^{2}$ and Arfa Saif ${ }^{3}$ \\ ${ }^{1,2}$ Departnment of Zoology, University of Agriculture, Pakistan \\ ${ }^{3}$ Guizhou Normal University, China
}

Received: December 29, 2017; Published: January 09, 2018

*Corresponding author: Safi Ur Rehman Qamar, Departnment of Zoology, Wildlife and Fisheries, Faculty of Science, University of Agriculture, Faisalabad, Pakistan, Email: ranasafi73@gmail.com

\begin{abstract}
We mostly know microorganisms by their negative impact that they are disease causing agents. But when we turn towards their positive impact that they also have an important impact on agriculture production by helping plants in their growth. Microorganisms have been an integral part of soil since ever earth formed. They have the capability to turn soil into waste land and waste land into productive soil. They increase soil fertility by incorporating air, minerals and nitrogenous compounds. They contribute in increasing plant growth by providing essential elements, minerals that plants cannot utilize by their Owen. Microorganisms decompose organic matter to simpler form that can be easily uptake by plants.
\end{abstract}

Keywords: Microorganisms; Bacteria; Fertility; Mineralization

\section{Introduction}

The physical and chemical composition of soil varies throughout the earth [1,2]. A hand full of soil contains millions of microorganisms which function in increasing soil fertility and plant growth [3]. Usually, people think that microorganisms are agents of disease, however, they have direct role in increasing soil fertility. These microbes help in the decomposition of organic matter. Different microbes decompose different organic matter [4]. Due to their role in improving soil fertility has become major investigation subject during the recent past. Many nutrients develop in soil due to the biological transformation by the action of microorganism [5]. They effect soil functioning by making it fertile. The soil which contain high number of microorganisms considered as most fertile soil. These microscopic creatures ensure the permanent existence of nutrients in soil. Successful agriculture is the result of management of these nutrients in soil [6].

In agro ecosystem, nutrient status in soil is determined by identification and quality of microorganisms [7]. This helps agriculturist to maintain these nutrients in soil to get greater yield of crops. The number of species of microorganism directly depends on the physical and chemical nature of soil [8]. Different studies have shown that microbial community structure is determined by environmental factors and chemical properties of soil [9-12]. Soil nutrients influenced due to land and soil management which results in process such as erosion, oxidation, leaching and mineralization.
Due to these processes, the activity of soil microorganism may increase or decrease which results in affecting soil fertility [13,14]. Both bacteria and fungi with organic matter may increase soil fertility and the production of soil [15-18].

\section{References}

1. Quesada CA, L Lloyd, NM Fyllas, R Paiva, Cruz, et al. (2010) Variations in chemical and physical properties of Amazon forest soils in relation to their genesis. Biogeosciences 7(5): 1515-1541.

2. Sharon L Spray» Matthew David Moran (2006) Tropical Deforestation. Lanham. Rowman \&Littlefield. P.48.

3. Christos, Clark JM, Shaw LJ (2014) The role of soil microbes in the global carbon cycle: tracking the belowground microbial processing of plant-derived carbon for manipulating carbon dynamics in agricultural systems. J Sci Food Agric 94(12): 2362-2371.

4. Schulz S, Brankatschk R, Dümig A, Kögel-Knabner, Schloter $M$, et al. (2013) The role of microorganisms at different stages of ecosystem development for soil formation. Biogeosciences 10(6): 3983-3996.

5. Kiflu A, Beyene S (2013) Effects of different land use systems on selected soil properties in south Ethiopia. Journal of Soil Science and Environmental Management 4(5): 100-107.

6. Zhang JE, Liu WG, Hu G (2002) The relationship between quantity index of soil microorganisms and soil fertility of different land use systems. Soil and Environmental Science 11(2): 140-143.

7. Lombard N, Prestat E, van Elsas JD, Simonet P (2011) Soil-specific limitations for access and analysis of soil microbial communities by metagenomics. FEMS Microbiol Ecol 78(1): 31-49. 
8. Hendrix PF, Parmelee RW, Crossley DA, Coleman DC, Odum EP, et al. (1986) Detritus food webs in conventional and no-tillage agro ecosystems. Bioscience 36(6): 374-380.

9. Grayston SJ, Campbell CD, Bardgett RD, Mawdsley JL, Clegg CD, et al. (2004) Assessing shifts in microbial community structure across a range of grasslands of differing management intensity using CLPP, PLFA and community DNA techniques. Appl Soil Ecol 25(1): 63-84.

10. Ibekwe AM, Poss JA, Grattan SR, Grieve CM, Suarez D (2010) Bacterial diversity in cucumber (Cucumissativus) rhizosphere in response to salinity, soil pH, and boron. Soil Biol Biochem 42(4): 567-575.

11. Strickland MS, Rousk J (2010) Considering fungal: bacterial dominance in soils -Methods, controls and ecosystem implications. Soil Biol Biochem 42: 1385-1395.

12. Celik I (2005) Land-use effects on organic matter and physical properties of soil in a southern Mediterranean highland of Turkey. Soil Tillage Res 83(2): 270-277.
13. Liu XL, He YQ, Zhang HL, Schroder JK, Li, et al. (2010) Impact of land use and soil fertility on distributions of soil aggregate fractions and some nutrients. Pedosphere 20(5): 666-673.

14. Minerdi, Fani R, Gallo R, Boarino A, Bonfante P (2001) Nitrogen fixation genes in an endosymbiotic Burkholderia strain. Appl Environ Microbiol 67(2): 725-732.

15. Rillig, Sara F Wright, Valerie T (2002) The role of arbuscular mycorrhizal fungi and glomalin in soil aggregation: comparing effects of five plant species. Plant Soil 238(2): 325-333.

16. Mortimer PE, Valentine AJ (2008) The role of arbuscular mycorrhizal colonization in the carbon and nutrient economy of the tripartite symbiosis with nodulated Phaseolus vulgaris. Soil Biol Biochem 40(5): 1019-1027.

17. Caesar-Tonthat, WB Stevens, M West, UM Sainju, Mark West, et al. (2014) Soil-aggregating bacterial community as affected by irrigation, tillage, and cropping system in the northern great plains. Soil Sci 179(1): 11-20.

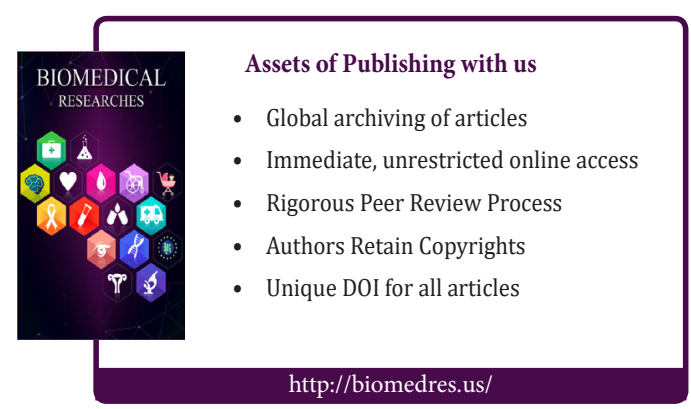

